\title{
Factors that influence the choice of a destination country for Brazilian foreign direct investment
}

Marcello Marchiano

Doutorando em Administração, com especialização em estratégia e governança corporativa,UNINOVE. Mestrado Profissional em Administração pela Fundação Escola de Comercio Alvares Penteado . MBA em Finanças pelo IBMEC e Formação em Economia pela PUC-SP. atua principalmente em empresas privadas nas funções de Diretor Presidente e Conselheiro de Administração, São Paulo, Brasil

m.marchiano@uol.com.br

Fernando Antonio Ribeiro Serra

Doutor em Engenharia pela Pontifícia Universidade Católica do Rio de Janeiro. Professor do Programa de Pós-graduação Stricto-Sensu da Universidade Nove de Julho - UNINOVE. Editor da Revista ĺbero-Americana de Estratégia/RIAE e coordenador da linha de pesquisa em Estratégia. Foi professor da UNISUL - Universidade do Sul de Santa Catarina e foi professor do Mestrado em Administração, São Paulo, Brasil

andoserra@stratscience.com.br

José Antônio de Sousa Neto

Graduado em Engenharia Civil pela Universidade Federal de Minas Gerais, MBA em International Banking and Finance e PhD em Accounting and Finance pela University of Birmingham no Reino Unido. Construiu carreira técnica e executiva no Lloyds Bank e nos grupos Andrade Gutierrez e Mendes Junior. É professor e pesquisador da Fundação Pedro Leopoldo e da Escola de Engenharia de Minas Gerais (EMGE), professor convidado da Fundação Dom Cabral e da Skema Business School (França) e professor afiliado da Seattle University (EUA), Minas Gerais, Brasil

jose.antonio.sousa@terra.com.br

Henrique Cordeiro Martins

Doutor em Administração pela UFMG, com estágio sanduíche na Birmingham School, Inglaterra. Mestre em Engenharia de Produção pela UFMG. MBA Executivo em Finanças e Mercado de Capitais pelo Instituto Brasileiro de Mercado de Capitais-IBMEC. Bacharel em Administração de Empresas e em Ciências pelos Centros Universitários Newton Paiva e Izabela Hendrix. Professor titular do programa de doutorado e mestrado acadêmico em Administração e de Sistema de Informações e Gestão do Conhecimento da Universidade FUMEC, Minas Gerais, Brasil henrique.martins@fumec.br

Editor Científico: José Edson Lara
Organização Comitê Científico
Double Blind Review pelo SEER/OJS
Recebido em 16.12.2017
Aprovado em 08.03.2018




\section{Abstract}

The objective of the article is to investigate the factors that influence the choice of the destination of Brazilian Foreign Direct Investment (FDI). This paper analyses especially if the decision regarding the locality is influenced by psychic distance. This article contributes to literature, firstly, by investigating the investment decisions of Brazilian companies from the theoretical perspective of psychic distance. Secondly, as Brazil is a country considered to have an emerging economy, it allows us to observe whether the results found in economies considered developed are repeated in developing localities. Linear regression was used to test the influence of differences in religion, language, industrial development, education, democratic level and political ideology, on the destination of Brazilian FDI. The results point to economic return as a determining factor in the internationalization process of Brazilian companies. Contrary to the theory of psychic distance, the most distant countries received the largest share of Brazilian multinational investments.

Keywords: FDI Determinant Factors; Brazilian FDI; Psychical Distance

\section{Fatores que influem na escolha de um país de destino para o investimento direto estrangeiro brasileiro}

\section{Resumo}

O objetivo do artigo é investigar fatores de influência para a definição do país de destino do Investimento Brasileiro Direto no Exterior (IDE), analisando-se especialmente se a decisão quanto à localidade é influenciada pelo distanciamento psíquico. Esse artigo contribui para literatura, em primeiro lugar ao investigar sob a ótica teórica do distanciamento psíquico as decisões de investimento das empresas brasileiras. Em segundo lugar, por se tratar de um país considerado emergente, o que permite observar se os resultados encontrados em economias consideradas desenvolvidas se repetem em localidades em desenvolvimento. Neste artigo é testada, por meio de regressões lineares, a influência das diferenças em religião, língua, desenvolvimento industrial, educação, nível democrático e ideologia política na seleção do país de destino do IED brasileiro. Os resultados apontam para o retorno econômico como um fator determinante do processo de internacionalização das empresas brasileiras. Contrariamente à teoria do distanciamento psíquico, os países considerados mais distantes receberam a maior parcela dos investimentos das multinacionais brasileiras.

Palavras-chave: Determinantes do IED; IED Brasileiro; Distância Psíquica. 


\section{Factores que influyen em la elección de um país de destino para la inversión extranjera directa brasileña}

\section{Resumen}

El objetivo del artículo es investigar los factores que influyen en la elección del destino de la Inversión Extranjera Directa (IED) brasileña. Este artículo analiza especialmente si la decisión con respecto a la localidad está influenciada por la distancia psíquica. Este artículo contribuye a la literatura, en primer lugar, al investigar las decisiones de inversión de las empresas brasileñas desde la perspectiva teórica de la distancia psíquica. En segundo lugar, como Brasil es un país que se considera que tiene una economía emergente, nos permite observar si los resultados encontrados en las economías consideradas desarrolladas se repiten en las localidades en desarrollo. Este artículo analiza por regresión lineal la influencia de las diferencias en religión, idioma, desarrollo industrial, educación, nivel democrático e ideología política, en el destino de la IED brasileña. Los resultados apuntan al rendimiento económico como un factor determinante en el proceso de internacionalización de las empresas brasileñas. Contrariamente a la teoría de la distancia psíquica, los países más distantes recibieron la mayor parte de las inversiones multinacionales brasileñas.

Palabras clave: factores determinantes de la IED; IED brasileña; distancia psíquica

\section{Introduction}

Studies on foreign direct investment are among the most frequent in the field of international business (Rugman, Verbeke, \& Nguyem 2011). New studies, however, which seek to clarify specific contexts and phenomena are important due to the influence of regional characteristics, of the different levels of economic development and of differences in the facility of access to resources among the global economies (Ferreira, Serra, \& Reis, 2011). Since 1900, Brazil has ceased to be merely a receiving country of FDI and has become, herself, an investor (Treviño \& Mixon, 2004). As it has an economy classified as emerging, an understanding of the influences on the choice of destination of FDI can help in understanding the internationalization process of emerging economies.

FDI can be defined as "an investment that crosses borders, by an entity resident in one economy with the objective of obtaining a lasting interest in a company resident in another economy" (Organisation for Economic Cooperation and Development - OECD, 2013). Multinational companies usually select their manners of entry, including for FDI, based on market imperfections and transaction costs (Ferreira \& Serra, 2015). In spite of Guisinger (2001) arguing that the adaptation of 
companies to the places for which they internationalize is the fundamental aspect of international business, economic and market motivations seem to have a still more significant role (Ferreira, et al., 2011; Bailey \& Li, 2015). The studies on FDI are complex (Bloningen \& Piger, 2011) either because of contextual and regional aspects (Rugman, Verbeke, \& Nguyem 2011) or because of the multiplicity of factors that influence investment decisions. Among these influencing factors, psychic (Johanson \& Vahlne, 1977), and cultural distance (Hofstede, 1980), are becoming prominent as factors that can influence the selection of the country chosen as the destination of investments.

Although many studies and theoretical approaches have been used in debating FDI, there are possibly two approaches that are central. Those based on macroeconomic factors (Groose \& Treviño, 1996); and those on adaptation and learning, related to psychic distances (Johanson \& Wiedrshein-Paul, 1975) and cultural (Kogut \& Singh, 1988). Economic considerations justify investment in more developed countries, among them, the United States and Japan (Dow \& Ferencikova, 2010) and they take into consideration macroeconomic variables, such as GDP, percapita income, inflation or exchange to explain the decision of the investment destination. Nevertheless, this perspective can provoke interpretative biases, because access to resources, including financial resources, diverges greatly between the large and the developing economies. In addition, institutional distancing, represented by market imperfections, customs barriers, the concentration of consumer markets, the scarcity of raw materials and the difference in the qualifications of labour, interfere in the capacity of companies to internationalize (Kostova, 1999).

The consideration of adaptation to the locality has been approached by theories of psychic and cultural distancing (Child \& Wong, 2002; Hofstade, 1980; 1983; Souza \& Bradley, 2006). The main presupposition is that the greater the psychic and cultural distance between two countries, the lower will be the propensity to investment. This distancing would influence the manner in which companies enter into a determined market, just as it would impose a hierarchy, and a prioritization of destinations (Dow \& Karunaratna, 2006). Nevertheless, the consideration of psychic and cultural distancing as determining factors in the destination of investments does not seem to find practical support (Harzing, 2003; Shenkar, 2001; Tihanyi, Griffith, \& 
Russell, 2005). The consideration is that the level of analysis should be that of the company and not be carried out with aggregate data, as a myriad of diverse cultures, values, and business objectives (Magnani, Zucchella, \& Floriani, 2018) are found when one considers macroeconomic data (Ellis, 2008; Evans \& Mavondo, 2002; Sousa \& Bradley, 2006).

The present work has the objective of investigating the influence of economic factors and psychic distancing on the choice of destination country for Brazilian FDI. Brazil has been continuously increasing its participation in world FDI, reaching $5 \%$ of the total investments made by developing economies in 2014 (UNCTAD, 2015). This research is justified initially due the inconsistency in the empirical results of previous studies regarding the factors of influence affecting decisions related to the destination of FDI, which are sometimes antagonistic. Additionally, to the extent that the authors could investigate, this research is also justified due to the lack of previous studies that evaluated psychic distancing as a factor of influence for the Brazilian FDI and due to the growing importance and participation of emerging economies in international FDI.

The questions on which this study is based are: what are the determining factors for Brazilian FDI? Is the investment decision influenced by psychic distance? Three hypotheses were tested: the first and second that relate positively Brazilian FDI to economic factors and the third with the object of testing the existence of a negative relationship between Brazilian FDI and psychic distancing. The findings indicate that the choice of destination of Brazilian FDI is related to economic factors and that psychic distancing did not demonstrate statistical significance for explaining the choice of destination of FDI.

\section{Conceptual development and hypotheses}

The studies for an ample understanding of FDI are based on three levels, with distinct motivations and sustaining theories. The first level is considered strategic and seeks to explain the reasons for company internationalization, based on economic theory (Neumann \& Hemais, 2005). The second level refers to the forms in which companies decide to internationalize, whether through exports, joint ventures or the establishment of wholly owned subsidiaries (Lu \& Bearmish, 2006). The second level is based on the theories of institutional distancing and transaction 
costs and is directly influenced by the specific characteristics of the countries, the country of origin and the country of destination (Tihanyi, Griffith, \& Russell; 2005). The third level refers to the locale for internationalization and is based on the concepts of transaction costs, measurement being effected by means of the psychic and cultural distances, the greater the distance between countries, the greater will be the transaction costs (Dow, 2000).

For this article the third level is especially important, that is, psychic distance. Psychic distance has been popularised as a factor that influences decisions regarding the destination of investments. To a certain extent, it is based on the concept of "risk avoidance", and has as its main premise the fact that companies will seek to make investments in environments they are better acquainted with (Dow \& Karunaratna, 2006). Differences result in distinct administrative and organizational practices, and also have an impact on the involvement of employees and on their expectations. In general, it is expected that the greater the distance between two countries the greater would be the costs of integration and administration (Lincoln, Hanada, \& Olson, 1981). The transaction costs would be higher, because the alignment would not be restricted to the administrative structure, but would also have to be applied to cultural practices and the behaviour of individuals (Jemison \& Sitkin, 1986).

In this paper it is argued that psychic distancing should exercise of influence regarding the destination of investments, but should not be considered in isolation for a decision on the destination of FDI. It is also argued that the economic motivations should provide the foundation for decisions regarding the choice of countries for FDI. In this way, this paper presents a conceptual model for testing the hypotheses. On the left-hand side of Figure 1 - Conceptual Model -the independent variables, dividends and the size of the destination country's market measured by its GDP and the volume of aggregate consumption are represented. It is assumed that there exists a positive relationship between the economic variables and the selection of the destination country for FDI. The second independent variable comprises the indicators of psychic distance and it is proposed that the greater the psychic distance between each pair of countries, the greater will be the negative effect on the choice of destination. On its right side the figure shows the independent variable, destination of the Brazilian FDI: 


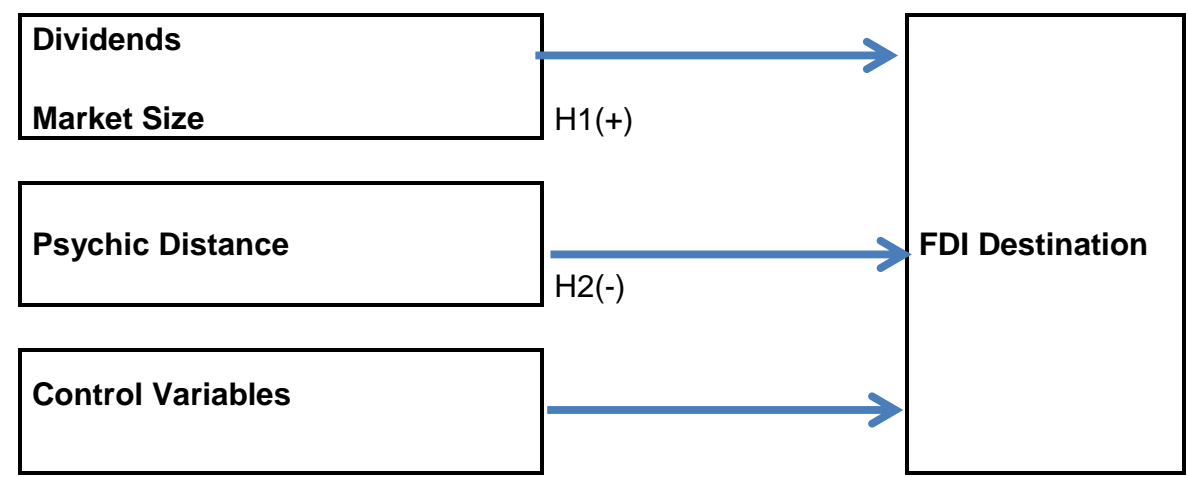

\section{Figure 1}

Conceptual model

Source: prepared by the authors

\subsection{Economic Factors}

Companies situated in emerging markets, especially the group denominated the BRICS (an acronym that refers to the founding member countries), composed of Brazil, Russia, India, China and South Africa, expanded their flow of direct investments to 145 billion dollars in 2012 (UNCTAD, 2015). Among the countries that make up the BRICS, the main highlight is China, which accounts for the largest slice of this investment. In the Brazilian case, in 2014 the FDI exceeded 24 billion dollars. Over the last nine years, Brazil invested on 19 billion dollars (BCB, 2016).

In a survey undertaken by Ávila, Rocha \& Ferreira da Silva (2015) 198 Brazilian multinational companies were listed with 587 subsidiaries spread over more than 84 countries. The fourteen Brazilian companies with the largest number of international subsidiaries are: Stefanini (32), WEG (31), Vale (27), Marcopolo (25), Banco do Brasil (24), Magnesita (22), Votorantim (21), Andrade Gutierrez (20), BRF (19), Gerdau (19), Itaú-Unibanco (19), IBOPE (17), Construtora Norberto Odebrecht (17) and Petrobrás (17). The Fundação Dom Cabral (FDC, 2015) makes available on its website an index of internationalization containing 51 Brazilian companies.

Brazil possesses a relatively discreet capital market when compared to the more mature markets because of the existence of a strong concentration in the capital structure of companies, even in public companies, producing, in consequence, a business network of a predominantly family nature and with a concentrated property structure (Saito \& Dutra, 2002). In addition, there is a strong participation of the state in the Brazilian economy, with large numbers of nationalized companies. Such characteristics can influence the internationalization process of 
Brazilian companies and their commitment to the long-term (Muritiba, 2009; Lima \& Barros, 2009).

The institutional barriers and transaction costs are notoriously high in Brazil, due to the tax burden, and precarious infrastructure, the qualification of labour or high financial costs (Lima \& Barros, 2009). The internationalization process of Brazilian companies can be considered late, the main motivating factors having been: the capturing of a part of international demand, the reduction of dependence on the local market and the increase of competitiveness (Lima \& Barros, 2009).

Studies that relate macroeconomic variables to the FDI are numerous (Corrêa \& Lima, 2008; Hiratuka \& Sarti, 2011). Especially in developed economies, variables such as the interest rate (Aliber, 1970), the size of the market and GDP (Ajami \& Barniv, 1984; Culem, 1988; Ray, 1990) and the country's risk (Kobrin, 1979; Tallman, 1988) have been evaluated as significantly related.

To reply to the first question that has guided this work, the determining factors of Brazilian FDI, this paper sets out from the premise that the economic factors have a significant relationship to the decision of Brazilian FDI destination, that is, Brazilian companies internationalize in the search for financial or marketing results (Ferreira, Reis, \& Serra, 2011).

To test the first hypotheses, it was considered that the choice of destination of Brazilian investment is associated: (1) with the return on investments measured by the return of capital in the form of dividends and; (2) with capturing a part of international demand (the search for new consuming markets and growth), measured through GDP and aggregate consumption of the country of destination. On this basis, the first two hypotheses were presented:

H1: Dividends are positively associated with the destination of Brazilian FDI.

H2: the GDP and aggregate consumption of the country of destination are positively associated with the choice of destination of Brazilian FDI. 


\subsection{Psychic distance}

The definition of elements that comprise psychic distance is not common to all authors and researchers. Johanson and Vahlne (1977), were the first to define the term psychic distance as: "the sum of the factors that avoid the flow of information between and to the market". Various elements have been considered for measuring psychic distancing. For the purposes of this article, however, those proposed by Dow and Karunaratna (2006) will be adopted. In the opinion of the authors the factors that should be taken into consideration to measure psychic distancing, and therefore the selection of the initial destination of direct investments to minimize risk and uncertainty, are six: language, religion, industrial development, education and the political system comprising the level of democracy and the political ideology of the party in power. Each of these factors requires a specific technique of measurement that will be presented in Chapter 3-Methods.

Psychic distance can be understood as a construct that hampers or prevents the flow of information between the company and the market. The differences in language, culture, education, among others, influence commercial practice and behaviour, increasing transaction costs and, in the final analysis, making access to certain markets difficult (Johanson \& Wiedershiem-Paul; 1975). In this way, large psychic distances can encourage companies to seek out markets and destinations closer to hand, mainly in the first stages of internationalization (Ellis, 2008).

The empirical evidence still is, however, limited. Some studies indicate a significant relationship between psychic distance (Dow, 2000) while others do not (Benito \& Gripsrud, 1992). The reasons for the disparities in the findings range from specific characteristics of companies to globalization as a mitigating factor of psychic distance (Ellis, 2008) to as pointed out by Chikhouni, Edwards and Farashahi (2017) that specific characteristics of the enterprises from developed and non-developed countries matters when measuring distances. In this paper it is argued that psychic distance is a proxy of the indirect measuring of uncertainty caused by the learning costs arising out of an investment decision in localities that are little understood (Ellis, 2008). On the other hand, the possible barriers of distancing can be overcome by the opportunities present in economies considered psychically distant.

In this way, the last research hypothesis that seeks to analyse if psychic distancing is enunciated, previously analysed for economies considered developed, 
generates an explanatory effect for a decision regarding the locality of FDI in an economy considered developing.

H3: Psychic distancing indicators, individually or in aggregate, influence negatively the decision on the destination of Brazilian FDI.

\section{Methodology}

The data relative to Brazilian FDI were obtained from the site of the Brazilian Central Bank (BCB, 2016), for the period between 2006 and 2014. Forty-nine distinct destinations for Brazilian FDI were encountered. However, excluding the countries considered tax havens and the localities with reduced or inconstant investment the final sample consisted of 34 countries: Argentina, Austria, Belgium, Canada, Chile, China, Colombia, Denmark, Ecuador, El Salvador, France, Germany, Hungary, Ireland, Israel, Italy, Japan, Luxemburg, Mexico, the Netherlands, Norway, Panama, Peru, Portugal, Puerto Rico, Russia, South Africa, Spain, Switzerland, Turkey, United Kingdom, United States, Uruguay and Venezuela.

To measure psychic distancing the same base of the countries above were used. The data were obtained from two sites. The first was that made available by Dow and Karunaratna (2016) containing all the data necessary to measure the distances: language, religion, industrial development, education and political system of each pair of countries. Once the data had been tabulated and the distances calculated the factorial loads and absolute values were calculated, as recommended by the authors.

For FDI, the concepts of Blomkvist \& Drogendijk (2013) were utilized, Buckley et al (2007) and Voss (2011), by means of linear regression, with one variable explained, control and explicative variables. The statistical software utilized was the SPSS - Statistical Package for the Social Sciences, version 20. Initially the descriptive statistics for all the variables were prepared, indicating the average, minimum, maximum and standard deviations. This information appears in Table $2-$ Descriptive Statistics. Additionally, after the analysis of the correlation matrix, the control variables that presented a high inflation of the variance, compromising the results of the regression were excluded. 
Finally, two models are presented: Model 1 with the explained variable dividends and Model 2 with the variables that comprise the psych distance index proposed by Dow and Ferencikova (2010). The index proposed by Dow and Ferencikova (2010) seeks to resolve the problems of multi-collinearity that Dow and Karunaratna's (2006) original scale presented. Basically, the difference in the scores are elevated to the fourth power and divided by the variance of the observations of each determined construct. After this has been done, the values are summed and the average calculated.

\subsection{Sample}

The Brazilian FDI in the period between 2006 and 2014 totalled 173 billion dollars, 36 billion were destined to tax havens and, therefore, excluded from the sample. Countries with a small or discontinuous volume of investment were also excluded. In this way, a total of 110 billion were considered, representing $81 \%$ of the total flow of Brazilian FDI. This procedure resulted in a sample of 34 countries, the United States being the country with the greatest flow of investments - $14.3 \%$, followed by Canada with $9.8 \%$ and the Netherlands with $8.9 \%$. Latin America received only $12 \%$ of Brazilian FDI, mentioning especially Argentina and Panama with $3.2 \%$ and $3.1 \%$ of the total. Such information does not bear out the presupposition of geographical proximity. Europe received $51 \%$ of the total with special mention for the Netherlands and Austria. North America received $24 \%$ of the investment (BCB, 2016).

The sectors object of Brazilian FDI were: farming, cattle raising and mineral extraction with $15 \%$ of the total; industry with $29 \%$ and the services sector with an expressive $55 \%$ of the total. Seventy-five percent of the investments in the services sector were directed to the establishment of holding companies and auxiliary financial services. This information on its own already allows us to suggest important characteristics of Brazilian FDI, such as, strong concentration of sectors and regions, mainly in the formation of company structures for Brazilian companies. 


\subsection{Dependent variable}

Destination of the FDI: the Brazilian FDI in the period between 2006 and 2014, in American dollars, made available by the Central Bank of Brazil - BCB (2016) measured for each country of destination.

\subsection{Independent variables}

Dividends: the justification for the choice of this variable is based on the proposal of this article, that the choice of the country of destination of Brazilian FDlis associated with economic return. The presupposition of the work is that Brazilian companies invest abroad in the search for return on their investments in the form of dividends. The dividends are measured by means of the natural logarithm of the annual values of the dividends received by Brazilian multinationals (Bacen, 2016).

Gross Domestic Product and Aggregate Consumption: Another presupposition is that Brazilian companies seek to expand their consuming markets. As a proxy to measure these markets the GDP of the destination country and its Aggregate Consumption, measured by means of the natural logarithms of the annual values were taken (UNCTAD; 2015).

Psychic distance: The other independent variables are the distances in culture, religion, language, level of industrialization, level of education and political system. They were measured between Brazil and the countries in which FDI is made. These distances were measured following the procedures proposed by Dow and Karunaratna (2006) described below.

The distancing in language is measured using three components. The first component (L1) is the distance between the main languages of each pair of countries, a 5 points scale being attributed from (1) same language to (5) different language families. The second and third components (L2 and L3) represent the proportion of individuals of a certain pair of countries capable of speaking the main language of the other and vice-versa. In these cases, also scores are applied from 
(1) $90 \%$ or more of the population speak the language of the pair to (5) less than $1 \%$ of the population can communicate in the language of the pair.

Religious distancing is also measured by means of three components. The first component (R1) is the distance between the main religion of each pair of countries (the main religion defined by the authors being that professed by more than $20 \%$ of the population), a scale of five points being attributed from (1) same belief to (5) different religious family (the definition of families can be encountered in Dow and Karunaratna (2016). The second and third components follow the same logic applied to languages ( $R 2$ and $R 3$ ) representing the proportion of individuals of a certain pair of countries devotees of the religion of the other and, vice-versa, five points scale also being applied from (1) $90 \%$ or more of the population holding the same belief to (5) less than $1 \%$ of the population having the same religion.

Educational distancing is measured by means of three components although differently from the two previous items. The first component (E1) is the absolute distance between the percentage of literate individuals over the age of fifteen in the two countries. For the second component (E2), initially the ratio is calculated of the number of individuals of a certain country with or at the second level of education by the estimate of the number of individuals of this determined country of age lower than fifteen. This calculation is made for each pair of countries and one percentage subtracted from the other. The third component (E3) is similar to the second, the only difference being that it was considered the number of individuals of a certain country with or at the third level of education. The definition of the second and third level of education is that adopted by the United Nations Organization (2016).

Distancing of the political system is measured using two dimensions. The first comprises four components and seeks to measure the level of democracy of a determined country. The second dimension comprises one only component and seeks to indicate the political ideology of the party in power.

For the first dimension, level of democracy, the first component (SP1) indicates the difference between the levels of political interference between each pair of countries according to the methodology proposed by Henisz (2000). The second component (SP2) measures the level of democracy between the two countries based on the concepts of Gleditsch (2003). The third (SP3) and fourth (SP4) components represent differences between the levels of political rights and civil liberty, 
respectively between each pair of countries, based on studies of Freedom House (2000).

The second dimension (SO1), political ideology is measured by means of the scale proposed by Beck et al. (2001), right-centre-left which is calculated based on the political ideology of the President of the Republic (or similar) and also of the largest political party which is a member of the coalition, the largest scores being given to the socialists. The absolute difference is calculated for each pair of countries.

Finally, the distancing in industrial development is calculated in nine components. The first component (DI1) is the difference between the Gross Domestic Product (American dollars) per capita between the countries. The second component (DI2) is the difference between the consumption of power between countries, calculated by means of a proxy of equivalent carbon kilogram. The third component (DI3) is the difference between the number of cars per one thousand inhabitants between the countries. The fourth component (DI4) is represented by the percentage difference of the non-agricultural workforce between the two countries. The fifth component (DI5) is the percentage difference between the urban populations of the two countries. The sixth component (DI6) is the difference between the number of newspapers per one thousand inhabitants between the two countries. The seventh component (DI7) is represented by the difference between the number of radios per one thousand inhabitants between the two countries. The eighth component (DI8) is the difference between the number of telephones per one thousand inhabitants between the countries. The ninth component (DI9) is represented by the difference between the number of televisions per one thousand inhabitants between the countries.

\subsection{Control variables}

Geographical distance: Smaller geographical distance makes possible better management and relationships between countries (Lerner, 1995) in spite of technological progress that reduces complexity (Grosse \& Treviño, 1996). Geographical distance is also utilised as a proxy to measure information asymmetry (Ragozzino, 2009). Geographical distance has also been considered as a proxy to 
measure cultural and psychic distancing (Kogut \& Singh, 1988; Grosse \& Goldberg, 1991; Bevan, Estrin, \& Meyer, 2004).

Macroeconomic: the value added of the country of destination of the FDI, the availability of labour, the volume of trade transactions between the countries, the number of foreigners from the country living in Brazil, as well as the number of Brazilians living abroad.

Table 1 - Variables of the model - presents all the variables considered in the model, their specification and source.

\section{Table 1}

\section{Variables of the Model}

\begin{tabular}{|c|c|c|}
\hline \multicolumn{2}{|c|}{ Variable Explained } & Source \\
\hline IDLN & ll logarithm of the average value of Brazilian Foreign Direct Investment (2006-2014) & $\begin{array}{l}\text { Central Bank } \\
\text { Brazil }\end{array}$ \\
\hline \multicolumn{3}{|c|}{ Control Variables (all variables are also available in total and average value) } \\
\hline VADDLN & $\begin{array}{l}\text { Natural logarithm of average value of Added Value by country of destination of the FDI } \\
(2006-2014)\end{array}$ & UNCTDA \\
\hline MOBLN & $\begin{array}{l}\text { Natural logarithm of the average number of workers of the country of destination of the FDI } \\
(2006-2014)\end{array}$ & UNCTDA \\
\hline EXPLN & Natural logarithm of Brazilian exports to the country of destination of FDI (2006-2014) & UNCTDA \\
\hline IMPLN & Natural logarithm of Brazilian imports from the country of destination of FDI (2006-2014) & UNCTDA \\
\hline DISTGEOLN & $\begin{array}{l}\text { Natural logarithm of the distance between the countries-measured in kilometres between } \\
\text { their capitals }\end{array}$ & www.br.distance.to \\
\hline BRASEXTLN & Natural logarithm of the number of Brazilians that live in each country & Ministry foreign affairs \\
\hline EXTBRASLN & Natural logarithm of the number of foreigners that live in Brazil, per country & $\begin{array}{l}\text { Ministry foreign } \\
\text { affairs }\end{array}$ \\
\hline \multicolumn{3}{|c|}{ Explanatory Variables } \\
\hline DIVLN & Natural logarithm of average value of returns of Brazilian Investments (2006-2014) & $\begin{array}{l}\text { Central bank of } \\
\text { Brazil }\end{array}$ \\
\hline GDPLN & $\begin{array}{l}\text { Natural logarithm of average value of GDP of country destination of Brazilian FDI (2006- } \\
\text { 2014) }\end{array}$ & UNCTDA \\
\hline \multirow[t]{2}{*}{ CONLN } & $\begin{array}{l}\text { Natural logarithm of average value of consumption of country destination of Brazilian FDI } \\
(2006-2014)\end{array}$ & UNCTDA \\
\hline & Language & $\begin{array}{l}\text { Dow and Karunaratna, } \\
(2016)\end{array}$ \\
\hline L1 & Distance between the main languages of each pair of countries & \\
\hline $\mathrm{L} 2$ & Frequency main language of $i$ in $j$ & \\
\hline L3 & Frequency main language of $\mathrm{j}$ in $\mathrm{i}$ & \\
\hline LFAT & $\begin{array}{l}\text { Factorial extracted for a factor of L1, L2 and L3 } \\
\text { Religion }\end{array}$ & $\begin{array}{l}\text { The authors } \\
\text { Dow and Karunaratna, } \\
\text { (2016) }\end{array}$ \\
\hline R1 & Distance between the main religions of each pair & \\
\hline $\mathrm{R} 2$ & Frequency main religion of $\mathrm{i}$ in $\mathrm{j}$ & \\
\hline $\mathrm{R} 3$ & Frequency main religion of $\mathrm{j}$ in $\mathrm{i}$ & \\
\hline RFAT & $\begin{array}{l}\text { Factorial extracted for a factor of R1, R and R3 } \\
\text { Industrial development }\end{array}$ & $\begin{array}{c}\text { The authors } \\
\text { Dow and Karunaratna, } \\
\text { (2016) }\end{array}$ \\
\hline I1 & Difference in per capita GDP between each pair of countries & \\
\hline $\mathrm{I} 2$ & Differences in power consumption (equivalent carbon kilogram per capita) per capita & \\
\hline $\mathrm{I} 3$ & Differences in cars per 1000 inhabitants between the countries & \\
\hline $\mathrm{I} 4$ & Percentage difference of non-agricultural workers between the countries & \\
\hline I5 & Percentage difference of the urban population between the countries & \\
\hline I6 & Difference in the number of newspapers per 1000 inhabitants between the countries & \\
\hline I7 & Difference in the number of radios per 1000 inhabitants between the countries & \\
\hline I8 & Difference in the number of telephones per 1000 inhabitants between the countries & \\
\hline
\end{tabular}


I9

IFAT

IFATABS .

\section{Education}

E1 Percentage difference between the number of literate adults between the countries

E2 Percentage difference of individuals with second educational level

E3 Percentage difference of individuals with third educational level

EFAT Factorial extracted for a factor of E1, E2 and E3

EFATABS Absolute value of the Factorial EFAT

Level of democracy

SP1 Difference between the institutional environments in the countries

SP2 Difference in the democratic level in the countries

SP3 Differences in political rights between the countries

SP4 Differences in civil liberty between the countries

SFAT Factorial extracted for a factor of SP1, SP2 SP3 and SP4

SPFATABS Absolute value of the Factorial SPFAT

Political ideology

SO1 Difference between the institutional environments in the countries
Factorial extracted for a factor of SO1

Absolute value of the Factorial SOFAT

https://sites.google.com/site/ddowresearch/home/scales
The authors

The authors

Dow and Karunaratna, (2016)

The authors

The authors

Dow and Karunaratna, (2016)

Henisz, W.J. (2000)

Gleditsch (2003)

Freedom House (2000)

Freedom House (2000)

The authors

The authors

Dow and Karunaratna, (2016)

Beck et al (2001)

The authors

The authors

Dow and Karunaratna, (2016)

Source: prepared by the authors

\section{Results - Descriptive statistics}

In Table 2 - Descriptive Statistics below, the average and the variation of the variables included in the models are presented.

\section{Table 2}

\section{Descriptive Statistics}

\begin{tabular}{crrrr}
\hline Variable & Minimum & Maximum & Average & $\begin{array}{c}\text { Standard } \\
\text { deviation }\end{array}$ \\
\hline IDE & 0.40 & 7.90 & 4.48 & 2.09 \\
DIVI & 1.40 & 6.50 & 3.98 & 1.52 \\
PIB & 10.00 & 16.60 & 13.11 & 1.60 \\
CONS & 9.90 & 16.40 & 12.80 & 1.59 \\
VADD & 9.70 & 16.50 & 12.92 & 1.68 \\
MOB & 5.50 & 13.60 & 9.35 & 1.58 \\
EXP & 8.50 & 14.40 & 12.01 & 1.44 \\
IMP & 9.10 & 14.70 & 11.97 & 1.41 \\
DIST & 7.60 & 9.80 & 8.85 & 0.56 \\
IDIO & 4.75 & 0.69 & 0.00 & 1.00 \\
INDUS & 0.01 & 1.86 & 0.83 & 0.53 \\
EDUC & 0.01 & 2.27 & 0.87 & 0.48 \\
DEMOC & 0.08 & 3.96 & 0.72 & 0.69 \\
IDEOL & - & 0.58 & 0.30 & 0.17 \\
RELIG & 0.59 & 2.70 & 0.00 & 1.00
\end{tabular}

Source: Prepared by the Authors 


\subsection{Evaluation of FDI per Variable}

For each country, in relation to Brazil, an evaluation of the amount of the FDI received was performed in order to identify if the countries considered nearest to Brazil received higher amounts and if the countries considered most distant received lesser amounts, as stated in the psychic distance theory. To perform this analysis the nearest five countries and the ones most distant to Brazil were selected and the FDI's behaviour for each group of countries were pointed out.

Table 3 - Psychic distance - presents the six dimensions proposed by Dow and Karunaratna (2006), distance in language, in industrial development, in level of education, in level of democracy, in religion and in political ideology. Some important points should be noted. The theory of psychic distancing proposed that the more distant countries were in each of the dimensions, the lower would be the values of FDI received. However, in observing the results in Table 3-Psychic distance, for the industrial, education and democratic distancing the results are the reverse of this. It is possible to see, in spite of the language, religion and cultural dimensions presenting greater FDI percentages for the nearest countries, the greatness is less significant than in the previous cases. Although it is here recognized that other factors may also influence the FDI's destination decision, as the influence of the Government (Wang et al; 2018), the institutional environment (Li, Cui, \& Lu, 2018) in absolute values the FDI for the most distant countries (measured by the criteria of Psychic distance), considering the complete sample, was more than the double compared to that received by countries considered nearest.

Table 3

Psychic distance

\begin{tabular}{ccccccc}
\hline & Language & $\begin{array}{c}\text { Industrial } \\
\text { development }\end{array}$ & Education & Democracy & Religion & Ideology \\
& Portugal & Mexico & China & Panama & El Salvador & Turkey \\
Countries & Luxemburg & South Africa & Venezuela & El Salvador & Venezuela & Spain \\
nearest Brazil & France & Chile & South Africa & Venezuela & Ecuador & Argentina \\
& El Salvador & El Salvador & El Salvador & Ecuador & Argentina & Peru \\
& Venezuela & Panama & Luxemburg & Argentina & Colombia & Uruguay \\
$\%$ FDI & $12 \%$ & $9 \%$ & $5 \%$ & $10 \%$ & $6 \%$ & $11 \%$ \\
$\%$ FDI TOT & $49 \%$ & $23 \%$ & $25 \%$ & $25 \%$ & $45 \%$ &
\end{tabular}




\begin{tabular}{|c|c|c|c|c|c|c|}
\hline \multirow{5}{*}{$\begin{array}{l}\text { Countries } \\
\text { most distant } \\
\text { from Brazil }\end{array}$} & Turkey & USA & Spain & China & Turkey & Denmark \\
\hline & China & Luxemburg & Canada & Peru & China & $\begin{array}{l}\text { United } \\
\text { Kingdom }\end{array}$ \\
\hline & Japan & Japan & Italy & Canada & Japan & Norway \\
\hline & Hungary & Canada & France & USA & Israel & Puerto Rico \\
\hline & Israel & Norway & Germany & Puerto Rico & $\begin{array}{l}\text { United } \\
\text { Kingdom }\end{array}$ & Ireland \\
\hline \multirow{2}{*}{$\begin{array}{c}\% \text { FDI } \\
\% . F D I \text { TOT }\end{array}$} & $1 \%$ & $42 \%$ & $21 \%$ & $38 \%$ & $3 \%$ & $4 \%$ \\
\hline & $51 \%$ & $77 \%$ & $75 \%$ & $75 \%$ & $55 \%$ & \\
\hline
\end{tabular}

Source: Prepared by the authors

The Table 4 - Economic Distance - presents the countries nearest and most distant relative to Brazil regarding economic factors, that is, GDP, aggregate consumption, value added, labour, gross capital formation, volume of exports and imports and geographical distance. It is possible to note that for all variables, excluding labour and geographical distance, the volumes of FDI were greater $(30 \%)$ for countries with greater distancing in relation to Brazil. Such facts provide partial support for hypotheses $\mathrm{H} 1$ and $\mathrm{H} 2$ that there exists a positive relationship between Brazilian FDI, the return on capital invested and the search for larger markets.

It is possible also to note, in evaluating the complete sample, that the FDI is uniformly distributed between the countries nearest to or geographically distant from Brazil. Geographical distance does not seem to exercise any influence on the decision to invest, countering the theory that geographical distance has an influence regarding the decision on the country of destination for FDI.

\section{Table 4}

Control variables

\begin{tabular}{|c|c|c|c|c|c|c|c|c|}
\hline & GDP & $\begin{array}{l}\text { Consum } \\
\text { p- } \\
\text { tion }\end{array}$ & $\begin{array}{l}\text { Added } \\
\text { value }\end{array}$ & Labour & $\begin{array}{l}\text { Capital } \\
\text { formatio } \\
n\end{array}$ & Exports & Imports & $\begin{array}{l}\text { Geog. } \\
\text { distance }\end{array}$ \\
\hline \multirow{4}{*}{$\begin{array}{l}\text { Countries } \\
\text { nearest } \\
\text { Brazil }\end{array}$} & Italy & Canada & $\begin{array}{l}\text { Canad } \\
\text { a }\end{array}$ & Russia & Spain & Ireland & Turkey & Uruguay \\
\hline & Russia & Spain & Russia & Japan & Russia & Austria & Austria & Peru \\
\hline & Canada & Russia & Spain & Mexico & Canada & Norway & Ireland & $\begin{array}{l}\text { Venezuel } \\
\text { a }\end{array}$ \\
\hline & $\begin{array}{l}\text { United } \\
\text { Kingdo } \\
\text { m }\end{array}$ & Italy & Mexico & Germany & Italy & $\begin{array}{l}\text { Denmar } \\
\mathrm{k}\end{array}$ & $\begin{array}{l}\text { Denmar } \\
\mathrm{k}\end{array}$ & Argentina \\
\hline
\end{tabular}




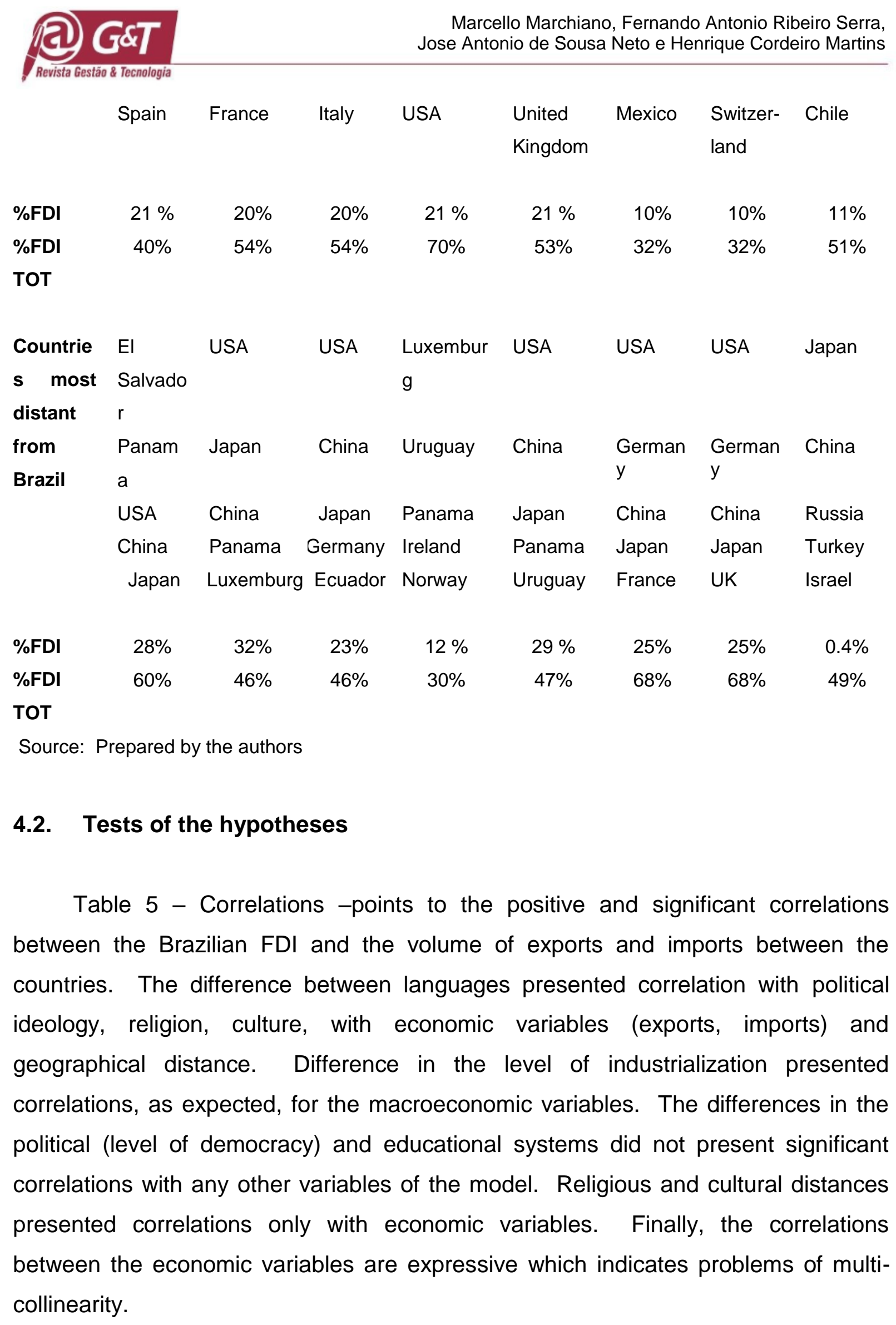




\section{Table 5}

Correlations

\begin{tabular}{|c|c|c|c|c|c|c|c|c|c|c|c|c|c|c|c|}
\hline & IDE & IDIOMA & INDUST & EDUCA & DEMOC & IDEOL & RELIG & PIB & EXP & IMP & DIST & EXT & BRA & MOB & DIV \\
\hline $\mathrm{IDE}$ & 1,000 & & & & & & & & & & & & & & \\
\hline IDIOMA & -332 & 1,000 & & & & & & & & & & & & & \\
\hline INDUST & 172 & ,204 & 1,000 & & & & & & & & & & & & \\
\hline EDUCA & -121 &,- 043 & 098 & 1,000 & & & & & & & & & & & \\
\hline DEMOC & -026 & ,175 & 119, & 153, & 1,000 & & & & & & & & & & \\
\hline IDEOL & -178 &, $383^{*}$ & -281 & ,046 & ,314 & 1,000 & & & & & & & & & \\
\hline RELIG & 209 &, $522^{*}$ & 158, & 041 & ,018 & ,098 & 1,000 & & & & & & & & \\
\hline PIB & 032 & ,333 & , 454" & 263 & 259 & $-0,035$ &, $422^{\circ}$ & 1,000 & & & & & & & \\
\hline EXP & 142 &, $415^{*}$ & ,525" & 265 & 199 & -,045 & $420^{\circ}$ & ,934" & 1,000 & & & & & & \\
\hline IMP & 156 &, $401^{\circ}$ & "477" & 248 & 215 & -037 & , $459^{\prime \prime}$ &, $939^{* *}$ &, $987^{* *}$ & 1,000 & & & & & \\
\hline DIST & 279 & ,631" &, $355^{\circ}$ & 162 & ,238 & 172 & ,673"* & ,493" &, $621^{*}$ &, $619^{* \prime}$ & 1,000 & & & & \\
\hline EXTRA &, $378^{\circ}$ & -062 & 235 & 116 & 142,- &,- 275 & -024 &, $461^{\prime \prime}$ &, $377^{*}$ &, $414^{\circ}$ & ;122 & 1,000 & & & \\
\hline BRAS &, $379^{\circ}$ & 143,- & , 465" & -091 & ,004 & $-396^{*}$ & ,037 &, $675^{* *}$ & ,628** &, $631^{* *}$ & 030 &, $747^{*}$ & 1,000 & & \\
\hline MOB & -038 & ,262 & 203 & 280 & ,227 &,- 073 &, 312 &, $837^{* *}$ & ,678* &, $702^{* *}$ & 215 &, $477^{* *}$ &, $529^{* \prime}$ & 1,000 & \\
\hline DIVID & ,514 & ,093 & ,418 & ,018 & 156,- & - 409 & 144,- &,- 196 & ,061 & -0,020 & 134,- & -0,085 & 055, & -240 & 1,000 \\
\hline
\end{tabular}

Source: Prepared by the authors

To test the hypotheses on the effect of the stimulation of psychic distance on Brazilian FDI, a series of regressions was carried out. Initially, high inflation of variance factors for the control variables were found due to their high correlation. Multicollinearity can have serious effects on regression coefficient estimates and on the applicability of the model. Although, without consensus, other methods can be used to address multicollinearity problems, in this research the variables that presented the highest indices were withdrawn (Hair et al., 2005, p.142).

Table 6 - Regressions- presents the results of the tests, Model 1 being the regression only with the explicative variable dividends and Model 2 the regression with the remaining explicative variables that make up psychic distancing (Dow \& Ferencikova, 2010). 
Table 6

Regressions

\begin{tabular}{lcc}
\hline & Model 1 & Model 2 \\
\hline Constant & & \\
\hline DIVLN & $0,62^{* *}$ & $0,84^{\star * *}$ \\
GDPLN & & \\
CONLN & & \\
VADDLN & & \\
MOBLN & & \\
EXPLN & & \\
IMPLN & & \\
DISTGEOLN & & \\
\hline
\end{tabular}

\begin{tabular}{ll}
\hline LANGUAGE & -1.430 \\
RELIGION & -0.686 \\
INDUSTRY & -0.277 \\
EDUCATION & -0.306 \\
DEMOCRACY & -0.052 \\
POLITICAL & 1.073 \\
IDEOLOGY & \\
\hline
\end{tabular}

\begin{tabular}{lll}
\hline R2 adjusted & $33.60 \%$ & $24.70 \%$ \\
\hline
\end{tabular}

${ }^{*} p<0.10 ;{ }^{* *} p<0.05 ; p<0.0^{* * *}$

Source: prepared by the authors.

In Model 1 the variable dividends presented statistical significance of $5 \%$ and an explanatory power $\mathrm{R}^{2}$ over33\%, indicating that dividends explain, to a high degree, decisions on Brazilian FDI. All the other control variables presented high variance inflation factors and were excluded from the model. In this way, support for $\mathrm{H} 1$ can be founded - dividends are related positively to the choice of country of destination for Brazilian FDI. The indicators selected for H2 - GDP and consumption were not statistically significant due to the high correlation between the variables and had to be removed from the model, making it impossible to test $\mathrm{H} 2$.

For Model 2, all the variables proposed by Dow and Karunaratna (2006) were included and tested in China by Blomkvist and Drogendijk (2013). The same methodological procedures were followed, however, in spite of the coefficients being negative as advocated by the theory, no variable giving a significant result. These results are not essentially different from those obtained by Blomkvist and Drogendjik (2012), where the addition to the Chinese model of psychic distances raised its explanatory power by $7 \%$. 


\section{Analysis and Discussion of the Results}

The starting point was the presupposition that the choice of destination of Brazilian FDI is motivated economically and seeks financial return. Brazilian FDI is positively related to dividends, indicating a priority economic motivation. Evaluating the destinations of Brazilian FDI, it was possible to find a strong concentration in economies with high GDP and market openness, which were measured by means of the volume of international trade transactions (exports and imports). Geographical distance did not present any significance. Brazilian FDI is more concentrated in European and North American countries than those bordering it, indicating that Brazilian multinationals go after large consumer markets regardless of whether they are geographically near.

The studies of Ávila, Rocha and Ferreira da Silva (2015) indicated that institutional distances possessed little influence on the decision about the manner of entry, whether by wholly owned subsidiary or joint ventures. And that Brazilian normative and regulatory factors are not high when compared to the developed countries. This characteristic could imply that Brazilian companies are prepared to deal with challenging environments. So that transaction costs would not be heightened. Our findings indicate that Brazilian companies destined the greater part of FDI for more developed markets, Europe with $51 \%$ and North America with $24 \%$ of the total, allowing us to suppose that Brazilian multinationals target countries with clearly established norms and rules.

The second decision-making perspective, in spite of not being the main object of the article, institutional distancing, based on the theory of Kostova (1999), also apparently is not borne out. The destination of Brazilian FDI is concentrated in countries with greater GDP, indicating a search for new, higher-income markets. For emerging economies like the Brazilian, institutional distance does not influence directly the choice of destination of Brazilian FDI; it appears to be more relevant for developed economies, where the options are greater.

Psychic distancing did not exercise influence on the destination of investments. Although other factors may influence the FDI destination's decision, contrary to the theory, countries more psychically distant received the larger part of Brazilian FDI. 
When evaluating the volume of Brazilian FDI for countries considered closer, culturally and psychically, the larger quantities were not destined for them. In this paper it was argued that for the growing process of internationalization of Brazilian companies, that the decision regarding the locality seems to follow more strategic presuppositions and the search for more mature markets, or the high transaction costs of the Brazilian economy invalidate the presuppositions of the theory.

The foundations of the specific country characteristics detailed by Rugman, Verbeke and Nguyen (2011), appear to be partially borne out. Evaluating the destinations of Brazilian FDI it was possible to found that economic characteristics influence the decisions of Brazilian multinationals. The specific Brazilian multinational characteristics were not tested, this being the first limitation of the study and also an opportunity for future studies. Nevertheless, evaluating the profile of Brazilian multinationals possessing a greater degree of internationalization, it was possible to encounter a predominance of industrial and non-services companies (FDC, 2015), characterised by their size, tradition and significant participation in the local market. Such factors suggest that Brazilian multinationals seek to exploit competences developed internally in new markets (Lima \& Barros, 2009).

A second limitation is the absence of non-aggregate data, as proposed in some theoretical models (Ellis, 2008; Evans \& Mavondo, 2002; Sousa \& Bradley, 2006). The proper level for measuring strategic decisions would not be the country, but rather the companies. The absence of such information limits the findings.

Future studies that contemplate indicators proposed by Dow and Karunaratna (2006) and amplified in Dow and Ferencikova (2010), also by Kostova (1999) and Hofstede (1980), can be carried out. Comparative studies between developed and developing economies would also have an academic relevance. Finally, a wideranging qualitative study on strategic motivators of Brazilian multinationals would allow the clear identification of the objectives of internationalization, justifying or contesting the results found here.

\section{Conclusions}

The article sought to investigate the determining factors in the choice of destination of Brazilian FDI seeking to understand if psychic distancing influences the decision regarding the locality. To reply to the first question that guided this research 
it was identified that the strategic factors, such as the search for return on capital invested and, to a certain extent, the size of the destination economy, influenced the decisions of Brazilian multinationals. For the second question, psychic distance, only the difference in languages proved to be a barrier for the internationalization process of Brazilian companies. Contrary to the theory, those countries considered psychically most distant were those that received the greater part of the investments.

The specific characteristics of each country seem to exercise an influence on decisions, principally when the GDP and the volume of international trade were evaluated. The specific characteristics of the companies were not studied. Nevertheless, the data obtained suggest, partially, that significant participation in the local market, its operational sector, and the tradition of the company facilitate its internationalization.

Finally, what this paper may be indicating for future research is that "money does not really have a homeland". The door that seems to be opening is that, in the end, what may count most is the "risk $\mathrm{x}$ return" relationship as translated to a purely financial perspective and the basic concept that "cash is king". Market professionals and experienced investors intuit / may say that they "know" it already, but there is not sufficient research / academic works that have helped bringing formal evidences that this actually happens in developing economies and perhaps even in developed ones. This paper presented one perspective, among others, to try to shed some clarity to the above implied "market wisdom".

\section{References}

Ajami, R. A., \& R. Barniv. (1984). Utilizing Economic Indicators in Explaining Foreign Direct Investment in the U.S. Management International Review, 24(4), 1626. DOI: https://doi.org/10.1016/0969-5931(95)00004-J

Aliber, R. Z. (1970). A theory of direct foreign investment. In C. P. Kindleberger (Ed.). The International Corporation. MIT Press, Cambridge, MA, United States.

Ávila, H. D. A., Rocha, A. D., \& Silva, J. F. D. (2015). Brazilian multinationals' Ownership mode: the influence of institutional factors and firm characteristics. BAR-Brazilian Administration Review, 12(2), 190-208.

Bailey, N., \& Li, S. (2015). Cross-national Distance and FDI: The Moderating Role of Host Country Local Demand. Journal of International Management, 21(4), 267- 
276. DOI:10.1016/j.intman.2014.11.002 or

https://ideas.repec.org/a/eee/intman/v21y2015i4p267-276.html

BCB - Banco Central do Brasil or BACEN (2016). Investimento Brasileiro direto no exterior: participação no capital. Recuperado de

http://www.bcb.gov.br/?SERIEFIND or

https://www.bcb.gov.br/htms/Infecon/SeriehistFluxolnvDir.asp

Benito, G., \& Gripsrud, G. (1992). The expansion of foreign direct investments: discrete rational location choices or a cultural learning process? Journal of International Business Studies, 23(3), 461-476. Recovered fromhttps://link.springer.com/article/10.1057/palgrave.jibs.8490275

Bevan, A., Estrin, S., \& Meyer, K. (2004). Institution building and the integration of Eastern Europe in international production. International Business Review, 13(1), 43-64. DOI:10.1016/j.ibusrev.2003.05.005 [ Links ]

Blomkvist, K., \& Drogendijk, R. (2013). The impact of psychic distance on Chinese outward foreign direct investments. Management International Review, 53(5), 659-686.

Bloningen, B., \& Piger, J. (2011). Determinants of Foreign Direct Investment. National Bureau of Economic Research. Working Paper 16704.

Buckley, P. J., Clegg, L. J., Cross, A. R., Liu, X., Voss H., \& Zheng, P. (2007). The determinants of Chinese outward foreign direct investment. Journal of International Business Studies, 38(4), 499-518.

Chikhouni, A., Edwards, G., \& Farashahi, M. (2017). Psychic distance and ownership in acquisitions: Direction matters. Journal of International Management, 23(1), 3242.

Child, J.,Ng, S. H., \& Wong, C. (2002). Psychic distance and internationalization: Evidence from Hong Kong firms. International Studies of Management \& Organization, 32(1), 36-56.

Corrêa, D., \& Lima, G. T. (2008). O comportamento recente do investimento direto brasileiro no exterior em perspectiva. Revista de Economia Política, 28(2), 249268.

Culem, C. (1988). Direct Investment Among Industrialized Countries, European Economic Review, 32, 885-904.

Dow, D. (2000). A note on psychological distance and export market selection. Journal of International Marketing, 8(1), 51-64.

Dow, D., \& Karunaratna, A. (2006). Developing a multidimensional instrument to measure psychic distance stimuli. Journal of International Business Studies, 37, 578-602. 
Dow, D., \& Ferencikova, S. (2010). More than just national cultural distance: Testing new distances scales on FDI in Slovakia. International Business Review, 19(1), 46-58.

Dow, D., \& Karunaratna, A. (2016). Sitio eletrônico dos autores com a metodologia de cálculo e base de dados. Recovered from https://sites.google.com/site/ddowresearch/home/scales

Ellis, P. (2008). Does psychic distance moderate the market size-entry sequence relationship? Journal of International Business Studies, 39(3), 351-369

Evans, J., \& Mavondo, F. T. (2002). Psychic distance and organizational performance: An empirical examination of international retailing operations. Journal of International Business Studies, 33(3), 515-532.

Ferreira, M. P., Serra, F., \& Reis, N. (2011). On the adaptation of the firm's strategies to the international business environment: a knowledge-based and evolutionary perspective. European J. of International Management, 5, p. 633-655.

Ferreira, M. P., \& Serra, F. R. (2015). Abordagem Conceitual às Estratégias de Internacionalização sob Pressões Institucionais Duais para Legitimidade e Conformidade/A Conceptual View of Internationalization Strategies under Dual Institutional Pressures for Legitimacy and Conformity. Revista de Administração Contemporânea, 19(4), 440.

Freedom House. (2000) Freedom in the World, [www document]. Recovered 27 Feb., 2018 from http://www.freedomhouse.org.

Fundação Dom Cabral - FDC (2015). Núcleo de negócios internacionais. Ranking FDC das Multinacionais Brasileiras. Recoverd from

https://www.fdc.org.br/blogespacodialogo/Documents/2015/ranking fdc multinac ionais brasileiras2015.pdf

Grosse, R., \& Goldberg, L.G. (1991). Foreign bank activity in the United States: an analysis by country of origin. Journal of Banking \& Finance, 15(6), 1093-1112.

Grosse, R., \& Treviño, L. (1996). Foreign Investment in The United States: an Analysis by Country of Origin. Journal of International Business Studies, 27(1), 139-155.

Guisinger, S. (2001). From OLI to OLMA: incorporating higher levels of environmental and structural complexity into the eclectic paradigm. International Journal of the Economics of Business, 8(2), 257-272.

Hair, Jr., J. H., Anderson, R. E., Tatham, R. L., \& Black, W. C. (2005). Análise Multivariada de Dados. (5a ed., A. S. Sant'Ana \& A. Chaves Neto Trads.). Porto Alegre: Bookman. 
Harzing, A. W. (2003). Acquisitions versus Greenfieldinvestments: Internationalstrategyand management ofentrymodes. Strategic Management Journal, 23(3), 211-227.

Henisz, W. (2000). The Institutional environment for Economic Growth. Economics and Politics, 12(1), 1-31.

Hiratuka, C., \& Sarti, F. (2011). Investimento direto e internacionalização de empresas brasileiros no período recente (No. 1610). Texto para Discussão, Instituto de Pesquisa Econômica Aplicada (IPEA). Recovered from http://repositorio.ipea.gov.br/bitstream/11058/1571/1/td 1610.pdf

Hofstede, G. (1980). Cultural consequences: International differences in work related values. Beverly Hills: Sage.

Hofstede, G. (1983). The cultural relativity of organizational practices and theories. Journal of international business studies, 14(2), 75-89.

Hofstede, G. (2016). The Hofstede Center. The dimensions of Organisational Culture. Metodologia de cálculo e base de dados. Recuperado em 9 jan., 2016 de http://geert-hofstede.com/countries.html.

Jemison, D., \& Sitkin, S. (1986). Corporate acquisitions: a process perspective. Academy of Management Review, 11, 145-163.

Johanson, J., \& Vahlne, J.-E. (1977). The Internationalization Process of the Firm: A Model of Knowledge Development and Increasing Foreign Market Commitments, Journal of International Business Studies, 8(1), 23-32.

Johanson, J., \& Wiedersheim-Paul, F. (1975). The internationalization of the firm: Four Swedish cases. Journal of Management Studies, 12, 305-322.

Kobrin, S. J. (1979). Political risk: A review and reconsideration. Journal of International Business Studies, 10(1), 67-80.

Kogut, B., \& Singh, H. (1988). The effect of national culture on the choice of entry mode. Journal of International Business Studies, 19(3), 411-432.

Kostova, T. (1999). Country institutional profile Concepts and measurement. Best Paper Proceedings of the Academy of Management, 180-184.

Lerner, G. H. (1995). Turn design and the organization of participation in instructional activities. Discourse Processes, 19(1), 111-131.

Li, M. H., Cui, L., \& Lu, J. (2018). Varieties in state capitalism: Outward FDI strategies of central and local state-owned enterprises from emerging economy countries. In State-Owned Multinationals (pp. 175-210). Palgrave Macmillan, Cham. 
Lincoln, J. R., Hanada, M., \& Olson, J. (1981). Cultural orientations and individual reactions to organizations: a study of employees of Japanese-owned firms. Administrative Science Quartely, 26 (1), 93-115.

Lima, L. A., \& Barros, O. (2009). The growth of Brazil's direct investment abroad and the challenges it faces. Columbia FDI Profiles, Vale Columbia Centre on Sustainable International Investment, 13.

Lu, J. W.,\& Beamish, P. W. (2006). Partnering strategies and performance of SMEs' international joint ventures. Journal of Business Venturing, 21(4), 461-486. Recovered from http://www.farzadalvi.com/wp-content/uploads/2012/01/Lu2006.pdf

Magnani, G., Zucchella, A., \& Floriani, D. E. (2018). The logic behind foreign market selection: Objective distance dimensions vs. strategic objectives and psychic distance. International Business Review, 27(1), 1-20.

Muritiba, S. N. (2009). Envolvimento dos Conselhos de Administração na estratégia das organizações. (Tese Doutorado em Administração. Faculdade de Economia, Administração e Contabilidade, Universidade de São Paulo, São Paulo, Brasil).

Neumann, R. W., \& Hemais, C. A. P. G. (2005). Produção internacional e comportamento organizacional no processo de internacionalização: podem as teorias explicar o comércio internacional? In C. A.P. G. Hemais. (Org.). O desafio dos mercados externos: teoria e prática na internacionalização da firma. Rio de Janeiro: Mauad, pp. 15-64

Organisation for Economic Co-Operationand Development - OECD (2016). Recovered from http://www.oecd.org/

Ragozzino, A. P. R. (2009). The effects of geographic distance on the foreign acquisition activity of US firms. Management International Review, 49(4), 509535. Recoverd from de https://papers.ssrn.com/sol3/cf dev/AbsByAuth.cfm?per id=362680

Rugman, A. M., Verbeke, A., \& Nguyen, P. C. Q. T. (2011). Fifty years of international business theory and beyond. Management International Review, 51(6), 755-786.

Saito, R., \& Dutra, M. G. L. (2002). Conselhos de Administração: análise de sua composição em um conjunto de companhias abertas brasileiras. Revista de Administração Contemporânea, 6(2), 9-27. Recovered from http://www.spell.org.br/documentos/ver/17247/conselhos-de-administracao-analise-de-sua-composicao-em-um-conjunto-de-companhias-abertas-brasileiras

Shenkar, O. (2001). Cultural distance revisited: Towards a more rigorous conceptualization and measurement of cultural differences. Journal of International Business Studies, 32(3), 519-536. Recovered from https://econpapers.repec.org/RePEc:pal:jintbs:v:32:y:2001:i:3:p:519-535 
Sousa, C. M. P., \& Bradley, F. (2006). Cultural distance and psychic distance: Two peas in a pod? Journal of International Marketing, 14(1), 49-70. DOI: https://doi.org/10.1509/jimk.14.1.49

Tallman, S. B. (1988). Home country political risk and foreign direct investment in the United States Journal of International Business Studies, 19(2): 219-234. Recovered fromhttps://link.springer.com/article/10.1057/palgrave.jibs.8490856

Tihanyi, L., Griffith, D. A., \& Russell, C. J. (2005). The effect of cultural distance on entry mode choice, international diversification and MNE performance: A metanalysis. Journal ofInternational Business Studies, 36(3), 270-283. Recovered from https://econpapers.repec.org/RePEc:pal:jintbs:v:36:y:2005:i:3:p:270-283

Treviño, L. \& Mixon, F. (2004). Strategic factors affecting foreign direct investment decisions by multinational enterprises in Latin America. Journal of World Business, 39, 233-243.

United Nations Conference on Trade and Development (UNCTAD) (2015). World Investment Report. United Nations Publications .Recovered fromhttp://unctad.org/en/pages/PublicationWebflyer.aspx?publicationid=1555

United Nations Organization (2016). Disponível em: http://unstats.un.org/unsd/demographic/products/socind/ acesso em 11/01/2016

Voss, H. (2011). The Determinants of Chinese Outward Direct Investment. Cheltenham: Edward Elgar. Recovered from https://scholar.google.com.br/scholar?q=Voss, + H.+(2011).+The+Determinants +0 f+Chinese+Outward+Direct+Investment.+Cheltenham:+Edward+Elgar.\&hl=ptBR\&as $\mathrm{sdt}=0$ \&as vis $=1$ \&oi=scholart\&sa=X\&ved=0ahUKEwjMuY2I7orYAhXDx5 AKHXRrCXMQgQMIJTAA

Wang, C., Hong, J., Kafouros, M., \& Wright, M. (2018). Exploring the Role of Government Involvement in Outward FDI from Emerging Economies. In StateOwned Multinationals (pp. 75-109). Palgrave Macmillan, Cham. 